\title{
Biological control of poplar anthracnose caused by Colletotrichum gloeosporioides (Penz.) Penz. \& Sacc.
}

\author{
Huayi Huang ${ }^{{ }^{*}}$, Chengming Tian², Yonghuai Huang ${ }^{1}$ and Huanhua Huang ${ }^{1}$
}

\begin{abstract}
Poplar anthracnose is one of the most serious diseases caused by the fungal pathogen Colletotrichum gloeosporioides (Penz.) Penz. \& Sacc. Biocontrol is an efficient green way for the disease control, and numerous researches have focused on exploring the potential biocontrol bacteria strains against C. gloeosporioides. In this study, antifungal activities against C. gloeosporioides of 108 rhizosphere soil isolates from healthy polar plants were investigated in vitro by the dual culture assay. The results suggested that strain $\mathrm{ZSH}-1$ showed the highest level of antifungal activity, as it inhibited C. gloeosporioides at a distance of $10.00 \mathrm{~mm}$. Based on the morphological, physiological-biochemical characteristics, and phylogeny analysis, strain ZSH-1 was identified as Bacillus subtilis. The sterile culture filtrate, crude protein, and crude lipopeptide extracts from the culture filtrate, and volatile compound(s) of ZSH-1 displayed a strong antagonism towards 7 fungal phytopathogens (C. gloeosporioides, Fusarium oxysporum, Alternaria tenuissima, Cytospora chrysosperma, Botryosphaeria dothidea, Mucor sp., and Absidia sp.), with inhibition rates ranging from 44.0 to 89.1\%, 26.7 to $85.4 \%, 11.6$ to $89.7 \%$, and 7.8 to $63.2 \%$, respectively. Moreover, $\mathrm{ZSH}-1$ exhibited cell wall-degrading traits by producing 3 lytic enzymes (cellulose, $\beta-1,3-$ glucanase, and protease). Finally, the greenhouse studies also revealed that strain ZSH-1 had a 47.6\% (12 days) efficacy in controlling poplar anthracnose when compared with the control. In concluding, obtained results demonstrate the potential biocontrol effect of $\mathrm{B}$. subtilis $\mathrm{ZSH}-1$, and it can be used as a promising biocontrol agent against poplar anthracnose and other fungal phytopathogens.
\end{abstract}

Keywords: Colletotrichum gloeosporioides, Poplar anthracnose, Fungal phytopathogens, Antifungal activity, Bacillus subtilis

\section{Background}

Poplar is one of the most important trees in China where it has a major role in farmland shelterbelts, soil conservation, and environmental protection. Poplar anthracnose, as a serious branch and leaf disease of poplar, is mainly caused by Colletotrichum gloeosporioides (Penz.) Penz. \& Sacc. The disease generally occurs in various poplar cultivated areas in the north and south of the country ( $\mathrm{Li}$ et al. 2012). Currently, applications of chemical fungicides are still the effective means to

\footnotetext{
*Correspondence: hhy19890408@163.com

'Guangdong Provincial Key Laboratory of Silviculture, Protection and Utilization, Guangdong Academy of Forestry, Guangzhou 510520,

Guangdong, China

Full list of author information is available at the end of the article
}

prevent the infection and dispersal of poplar anthracnose (Song et al. 2016). However, the excessive and long-term use of chemical fungicides has led to the evolution of drug resistance of pathogenic fungi. Even more, chemical fungicides result in serious environmental pollution because of the difficult degradation and non-target toxicity (Furuya et al. 2011). Therefore, more and more researches have focused on developing and applying alternative methods that are less reliant on fungicides and more environmentally friendly. Biological control is high efficiency and safer for the environment to be used in disease management (Shafi et al. 2017).

Many microorganisms have been used for the control of fungal phytopathogens. Among them, the Bacillus

\section{Springer Open}

(๑) The Author(s). 2020 Open Access This article is licensed under a Creative Commons Attribution 4.0 International License, which permits use, sharing, adaptation, distribution and reproduction in any medium or format, as long as you give appropriate credit to the original author(s) and the source, provide a link to the Creative Commons licence, and indicate if changes were made. The images or other third party material in this article are included in the article's Creative Commons licence, unless indicated otherwise in a credit line to the material. If material is not included in the article's Creative Commons licence and your intended use is not permitted by statutory regulation or exceeds the permitted use, you will need to obtain permission directly from the copyright holder. To view a copy of this licence, visit http://creativecommons.org/licenses/by/4.0/. 
genus is recognized as a promising group with a wide distribution in soils. Due to their strong antagonistic activity, broad inhibitory spectrum, and high viability, members of the Bacillus species have been effectively used in controlling soil-borne, air-borne, and postharvest diseases (Pérez-García et al. 2011; Shafi et al. 2017). Antagonistic strains control fungal phytopathogens through several mechanisms, such as competition, mycoparasitism, the production of antibiotics, and the induction of defense responses (Guo et al. 2019; Jinal and Amaresan 2020). Production of a variety of metabolites is an important mechanism by which the Bacillus genus exerts biocontrol. These inhibitory metabolites are mainly including lipopeptides, proteins, and volatile compound(s) (Baysal et al. 2013; Shafi et al. 2017). In addition, lysates of antagonistic bacteria have also been reported to possess antifungal activity (Yu et al. 2013).

The objectives of this study were to explore the potential biocontrol antagonistic bacteria from rhizosphere soil against the poplar anthracnose pathogen C. gloeosporioides and to identify the strain, characterize the main ingredients for antagonistic, and clarify the cell walldegrading traits.

\section{Materials and methods Fungal phytopathogens}

Seven fungal phytopathogens (Colletotrichum gloeosporioides CFCC80308, Fusarium oxysporum CFCC82468, Alternaria tenuissima CFCC84533, Cytospora chrysosperma CFCC 89600, Botryosphaeria dothidea CFCC82975, Mucor sp. CFCC80870, and Absidia sp. CFCC80375) were provided by China Forestry Culture Collection Center (CFCC). These fungi were maintained on potato dextrose agar (PDA) slants at $4{ }^{\circ} \mathrm{C}$ and grown on PDA plates at $28^{\circ} \mathrm{C}$ when used.

\section{Isolation of rhizobacteria}

Rhizobacteria were isolated from the rhizosphere soil of healthy poplar plants in Haidian and Changping districts of Beijing City, China. Five grams of soil sample was transferred to $45 \mathrm{ml}$ of sterilized water and shaken at $200 \mathrm{rpm}$ for $20 \mathrm{~min}$ prior to use (Kurabachew and Wydra 2013). Gradient dilutions of the soil suspension were spread onto Luria-Bertani (LB) agar plates, and the plates were incubated at $30^{\circ} \mathrm{C}$ in darkness. A single bacterial colony that is well separated from the other colonies were selected and re-streaked onto a new LB agar plate with an inoculating loop. Then, the plate was incubated at $30^{\circ} \mathrm{C}$ for $24 \mathrm{~h}$, and then stored at $-80^{\circ} \mathrm{C}$ in LB with $30 \%$ glycerol (v/v).

\section{In vitro screening of rhizobacteria against $C$. gloeosporioides}

The rhizobacteria isolates were screened for antifungal activity against C. gloeosporioides using the dual culture assay described by Huang et al. (2014). The inhibition distance was defined as the width of the inhibition zone between the bacterial and fungal strains. The strain showed the highest antifungal activity was selected for further study.

\section{Morphology, culture conditions, and physiological- biochemical characteristics of selected strain}

Morphology, culture conditions, and physiologicalbiochemical characteristics were performed according to previously published methods of Dong et al. (2001) and Furuya et al. (2011).

\section{Phylogenetic analysis of selected strain}

The 16S rRNA gene was amplified and sequenced, using a single intact colony of selected strain according to a previously described method (Huang et al. 2014). The primers 63f (5'-CAGGCCTAACACATGCAAGTC-3') and 1387r (5'-GGGCGGWGTGTACAAGGC-3') were used for amplification. Polymerase chain reaction (PCR) conditions were as follows: $94{ }^{\circ} \mathrm{C}$ for $4 \mathrm{~min}, 35$ cycles of $95^{\circ} \mathrm{C}$ for $1 \mathrm{~min}, 55^{\circ} \mathrm{C}$ for $1 \mathrm{~min}$, and $72^{\circ} \mathrm{C}$ for $1.5 \mathrm{~min}$, and a final extension at $72{ }^{\circ} \mathrm{C}$ for $10 \mathrm{~min}$. The PCR products were sequenced by Invitrogen Corporation (Beijing, China). The sequences were blasted in the GenBank database, using a blastn search and aligned using Clustal W (ver. 1.82). Phylogenetic analysis was performed using MEGA (ver. 5.0) and a neighbor-joining phylogenetic tree was constructed by bootstrap analysis with 1000 replicates.

\section{Evaluation of the effects of sterile culture filtrate}

The strain selected from the in vitro test was grown in $100 \mathrm{ml}$ modified medium no. 3 ( $\mathrm{g} \mathrm{L}^{-1}$; glucose 10.0, peptone 5.0, soybean meal 5.0, $\mathrm{KH}_{2} \mathrm{PO}_{4} 1.0, \mathrm{MgSO}_{4} \cdot 7 \mathrm{H}_{2} \mathrm{O}$ $0.5, \mathrm{NH}_{4} \mathrm{Cl} 3.0, \mathrm{Na}_{2} \mathrm{HPO}_{4} 1.0$, and yeast extract $0.5 ; \mathrm{pH}$ 7.0-7.2) in a 500-ml Erlenmeyer flask at $28^{\circ} \mathrm{C}$ with 200 $\mathrm{rpm}$. Culture broth was incubated for 3 days and centrifuged with $10,000 \mathrm{rpm}$ at $4{ }^{\circ} \mathrm{C}$ for $20 \mathrm{~min}$. Sterile culture filtrate (SCF) was obtained by passing the supernatant through a sterile membrane filter $(0.22 \mu \mathrm{m}$; Pall, Ann Arbor, USA). The antifungal effects of SCF against 7 fungal phytopathogens were assayed by measuring the mycelial growth inhibition rates (Song et al. 2012). Briefly, $2 \mathrm{ml}$ of SCF was mixed with $20 \mathrm{ml}$ of PDA at $40-45^{\circ} \mathrm{C}$ in a culture plate; no SCF was added for the control. After the medium was solidified, freshly growing fungal mycelial plugs $(6 \mathrm{~mm})$ were collected and inoculated onto the center of the plate using a sterile steel borer. The plates were incubated at $28^{\circ} \mathrm{C}$. The diameters of the fungal colonies were measured when those of the control colonies covered more than three quarters of the diameter of the dish according to the crisscross method. All experiments were repeated 3 times. The percentage 
of growth inhibition was calculated using the following formula (Yang et al. 2011):

$$
P(\%)=100 \times[(C--d)--(T--d)] /(C--d)
$$

where $P$ is the inhibitory rate, $C$ is the diameter of a control colony, $T$ is the diameter of a treated colony, and $d$ is the diameter of the mycelial plug.

\section{Evaluation of the effects of crude protein and crude lipopeptide extracts}

Crude protein and crude lipopeptide extracts were obtained respectively from SCF according to a previously described method (Huang et al. 2014). Then, the extracts were sterilized by passing through a sterile membrane filter $(0.22 \mu \mathrm{m}$; Pall). The antifungal effects of crude protein and crude lipopeptide extracts against 7 fungal phytopathogens were assayed by measuring the mycelial growth inhibition rates using the procedure described above.

\section{Evaluation of the effects of volatile compound(s)}

The antifungal effects of the volatile compound(s) (VOCs) against the 7 fungal phytopathogens were tested by co-cultivating the fungi and bacteria on twocompartment plates (Yuan et al. 2012). One half of each plate was filled with PDA, while the other half contained TYB medium. A 6-mm diameter fungal plug was placed on the PDA side, and the candidate antagonistic strain was inoculated on the other side $24 \mathrm{~h}$ later. Plates not inoculated with the test strain served as the controls. Then, the plates were sealed with parafilm and incubated at $28^{\circ} \mathrm{C}$. The diameters of fungal colonies and percentages of growth inhibition were measured as described above. All experiments were repeated three times.

\section{Characterization of cell wall-degrading traits}

The cellulase activity and $\beta-1,3$-glucanase activity of the test strain was determined, using a method described previously (Essghaier et al. 2009). The activities of $\beta-1,3-$ glucanase, chitinase, protease, and lipase were determined using aniline blue pachyman agar plate, $0.2 \%$ colloidal chitin plate, skim milk agar plate, and $1 \%$ Tween 80 agar plate, respectively (Dong et al. 2001; Gao et al. 2009; Ren et al. 2013). Briefly, a single colony of test strain collected from an overnight culture was seeded onto the center of the plates; then, the plates were monitored for the appearance of a clear zone around the developing bacterial colonies at $28^{\circ} \mathrm{C}$.

\section{Evaluation of biocontrol activity of the candidate strain under greenhouse conditions}

To evaluate the biocontrol activity of the candidate strain towards poplar anthracnose caused by C. gloeosporioides, a pot assay was performed using 1-year-old poplar seedlings (Populus xeuramericana cv. '74/76') with 7-10 expanded leaves (Huang et al. 2014). Each treatment consisted of 15 plants with 3 replicates (5 plants per replicate). Three treatments were set up as follows: SZ, the candidate strain and C. gloeosporioides sprayed on leaves at the same time; CK1, only sterile distilled water sprayed on leaves; and CK2, leaves only sprayed with $C$. gloeosporioides. For the phytopathogen inoculation, a spore suspension $\left(1.0 \times 10^{5}\right.$ spores $\left.\mathrm{ml}^{-1}\right)$ of C. gloeosporioides was sprayed on both sides of the leaves ( $2 \mathrm{ml}$ per leaf) using an artist's airbrush (YD12F111, Yudi, Zhejiang, China). Sterile distilled water and the suspension $\left(1.0 \times 10^{9} \mathrm{cfu} \mathrm{ml}^{-1}\right)$ of the candidate strain were sprayed on the leaves using the same method as for C. gloeosporioides. The diseased leaves rate (DLR), disease severity (DS), disease index (DI), and greenhouse control efficacy (GCE) were investigated 12 days after $C$. gloeosporioides inoculation, respectively. The DS was expressed as a percentage of lesion area over the total surface area per leaf and divided into 6 ratings: 0 , no lesion; 1 , lesion area $\leq 5 \%$; 2 , lesion area $5-25 \%$; 3 , lesion area $25-45 \%$; 4 , lesion area $45-65 \%$; and 5 , lesion area > $65 \%$. The DLR, DI, and GCE were calculated using the following formulas:

$$
\begin{aligned}
& \text { DLR }(\%)=100 \times(\text { No.of affected leaves } / \text { No.of total leaves }) \\
& \text { DI }=\left[100 \times \sum(\text { No.of affected leaves } \times \text { corresponding DS })\right] /(\text { No.of total leaves } \times 5) \\
& \text { GCE }(\%)=100 \times[(\text { DI of CK } 2-- \text { DI of CK1 }) \\
& --(\text { DI of SZ treatment }-- \text { DI of CK1 })] /(\text { DI of CK2 }-- \text { DI of CK1 })
\end{aligned}
$$

\section{Statistical analysis}

The mean values and standard deviations were calculated, and statistically compared using analysis of variance (ANOVA) and Duncan's multiple range tests ( $p \leq$ 0.05) using SPSS software version 20.0 (SPSS Inc., Chicago, Illinois).

\section{Results and discussion}

Isolation and screening of antifungal bacteria in vitro

A total of 108 bacterial isolates were obtained from 5 rhizosphere soil samples, and 15 of them showed antifungal activity in vitro. Of the 15 bacterial strains, $\mathrm{ZSH}-$ 1 showed the highest level of antifungal activity, as it inhibited C. gloeosporioides at a distance of $10.00 \mathrm{~mm}$ (Table 1). Strain ZSH-1 was deposited in China General Microbiological Culture Collection Center (no. 9025). Microorganisms that grow in plant rhizosphere are widely used as biocontrol agents. Islam et al. (2018) reported that Pseudomonas aeruginosa BA5 isolated from rhizosphere of plants suppressed the growth of $F$. oxysporum (the causal agent of Fusarium wilt). Karthika et al. (2020) reported that B. cereus KTMA4 from tomato rhizosphere showed the highest inhibition against major phytopathogens of tomato. 
Table 1 Antifungal activities of rhizobacteria isolates against C. gloeosporioides in vitro

\begin{tabular}{lll}
\hline Isolate & Location & $\begin{array}{l}\text { Inhibition distance } \\
(\mathrm{mm})\end{array}$ \\
\hline ZSH-1 & Haidian district of Beijing City, China & $10.00 \pm 0.00 \mathrm{a}$ \\
ZSH-3 & $8.1 \pm 0.20 \mathrm{~b}$ \\
ZSH-9 & $4.83 \pm 0.42 \mathrm{fg}$ \\
ZSH-14 & $3.93 \pm 0.65 \mathrm{~h}$ \\
HKB-5 & $5.97 \pm 0.95 \mathrm{e}$ \\
HKB-12 & $2.17 \pm 0.29 \mathrm{i}$ \\
HKB-17 & $7.63 \pm 0.15 \mathrm{~b}$ \\
HHY-7 & Changping district of Beijing City, & $7.43 \pm 0.57 \mathrm{bc}$ \\
HHY-9 & China & $5.37 \pm 0.06 \mathrm{efg}$ \\
HHY- & $4.70 \pm 0.20 \mathrm{~g}$ \\
13 & \\
HSL-9 & $3.60 \pm 0.10 \mathrm{~h}$ \\
HSL-12 & $7.93 \pm 0.21 \mathrm{~b}$ \\
CYS-1 & $6.73 \pm 0.21 \mathrm{~d}$ \\
CYS-7 & $5.50 \pm 0.10 \mathrm{ef}$ \\
CYS-9 & $6.80 \pm 0.44 \mathrm{~cd}$
\end{tabular}

Values with the different letter within the same column are significantly different at $p \leq 0.05$ according to Duncan's test. Numbers followed by the " \pm " are standard errors $(\mathrm{SE})$

\section{Morphology, culture conditions, and physiological-} biochemical characteristics of strain $\mathrm{ZSH}-1$

The colonies of strain ZSH-1 grown on LB agar medium were off-white to gray-yellow, oblong, smooth, moist, and slightly convex and had an entire margin. The cells were rod-shaped, $0.5-0.8 \mu \mathrm{m}$ wide, and $1.2-2.5 \mu \mathrm{m}$ long. Strain ZSH-1 can grow at temperatures ranging from 10 to $50{ }^{\circ} \mathrm{C}$, in $\mathrm{pH}$ values ranging from 5 to 10 , and in $\mathrm{NaCl}$ concentrations ranging from 0.2 to $10 \%(\mathrm{w} / \mathrm{v})$ (Table 2). The morphological and physiological-biochemical characteristics of strain $\mathrm{ZSH}-1$ were found to be in complete accordance with B. subtilis, using interpreting software cluster analysis (Todorova and Kozhuharova 2010).

\section{Phylogenetic analysis of strain $\mathrm{ZSH}-1$}

Based on the morphological and physiologicalbiochemical characteristics, strain ZSH-1 was identified as B. subtilis. To precisely determine the species of strain ZSH-1, 1281 bp (GenBank accession KM114000.1) of the $16 \mathrm{~S}$ rDNA sequence was aligned with those of the most closely related $B$. subtilis by the Clustalx program. The 16S rDNA sequence of Escherichia coli U5/41 (GenBank accession NR_024570.1) was used as an out group. Bootstrap analysis showed strain ZSH-1 was grouped with $B$. subtilis (GenBank accession HE582781.1) with a sequence similarity of $89 \%$ (Fig. 1). The phylogenetic analysis of $16 \mathrm{~S}$ rDNA sequence revealed that strain ZSH-1 belongs to $B$. subtilis.
Table 2 Culture conditions and physiology-biochemical characteristics of strain $\mathrm{ZSH}-1$

\begin{tabular}{|c|c|}
\hline Indicator & Result \\
\hline Gram staining & + \\
\hline Mobility & + \\
\hline Growth at $4^{\circ} \mathrm{C}$ & - \\
\hline Growth at $10^{\circ} \mathrm{C}$ & + \\
\hline Growth at $50^{\circ} \mathrm{C}$ & + \\
\hline Growth at $55^{\circ} \mathrm{C}$ & - \\
\hline Growth at $\mathrm{pH} 4$ & - \\
\hline Growth at $\mathrm{pH} 5$ & + \\
\hline Growth at pH 5.7 & + \\
\hline Growth at $\mathrm{pH} 10$ & + \\
\hline Growth at pH 11 & - \\
\hline Growth with $0.2 \%(w / v) ~ N a C l$ & + \\
\hline Growth with $5 \%(w / v) ~ N a C l$ & + \\
\hline Growth with $10 \%(\mathrm{w} / \mathrm{v}) \mathrm{NaCl}$ & + \\
\hline Growth with $15 \%(\mathrm{w} / \mathrm{v}) \mathrm{NaCl}$ & - \\
\hline Liquefication of gelatin & + \\
\hline Phenylalanine deaminase test & - \\
\hline Hydrolysis of casein & + \\
\hline Hydrolysis of starch & + \\
\hline Methyl red reaction & - \\
\hline Catalase test & + \\
\hline Lecithinase test & + \\
\hline Oxidase test & + \\
\hline Reduction of nitrates & + \\
\hline Production of indole & - \\
\hline Production of hydrogen sulfide & + \\
\hline Voges-Proskauer reaction & + \\
\hline pH Voges-Proskauer broth & $6.89-7.13$ \\
\hline Decomposition of tyrosine & - \\
\hline Utilization of glucose & + \\
\hline Utilization of D-xylose & + \\
\hline Utilization of L-arabinose & + \\
\hline Utilization of mannitol & + \\
\hline Utilization of D-sorbitol & + \\
\hline Utilization of sodium malonate & + \\
\hline Utilization of sodium citrate & - \\
\hline Production of gas from glucose & - \\
\hline Anaerobic growth in glucose agar & - \\
\hline Production of acid through the decomposition of milk & + \\
\hline
\end{tabular}

+ , positive; -, negative

\section{Antifungal activities of sterile culture filtrate}

The SCF of ZSH-1 exhibited strong antifungal activities against 7 fungal phytopathogens (C. gloeosporioides, F. 


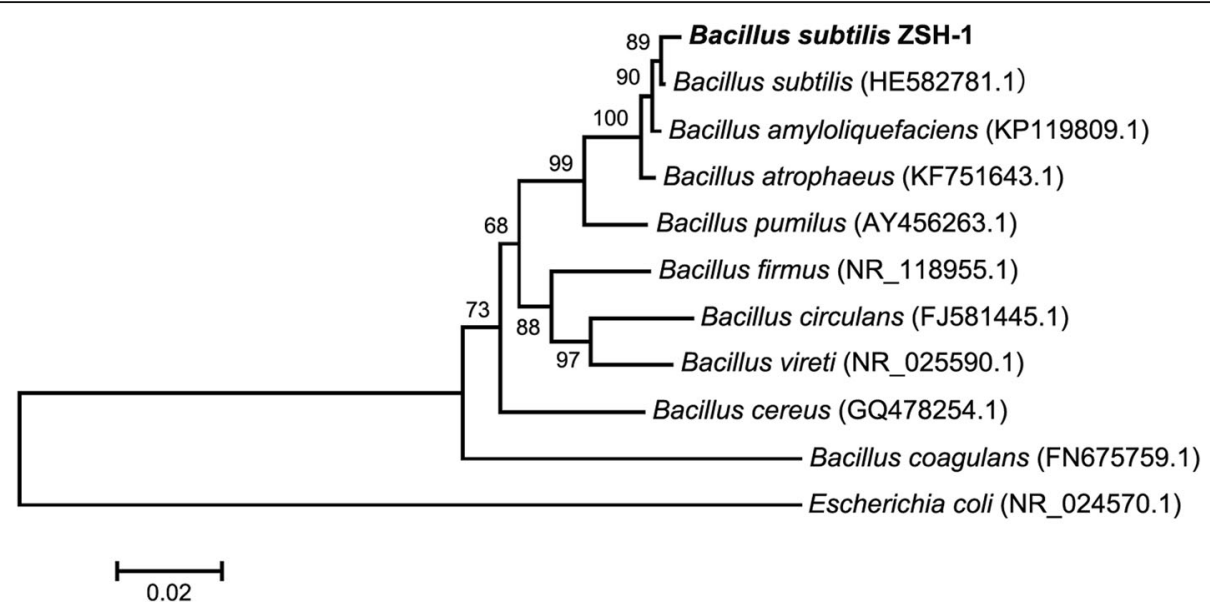

Fig. 1 Phylogenetic tree of strain ZSH-1 based on $16 \mathrm{~S}$ rRNA sequence analysis

oxysporum, A. tenuissima, C. chrysosperma, B. dothidea, Mucor sp., and Absidia sp.) belonging to various taxonomic groups. The inhibition rates ranged from 44.0 to $89.1 \%$ (Fig. 2a). Moreover, when the colonies of $C$. gloeosporioides were measured every day, the diameters were significantly reduced by treatment with SCF of $\mathrm{ZSH}-1$ than the control. The inhibition rate was gradually increased over time from day 1 to day 6 (Fig. 2b). The antifungal activity of sterile culture filtrate was also stable after treatment at temperatures from $40^{\circ} \mathrm{C}$ to $100^{\circ} \mathrm{C}$ for 30 min, or autoclaved at $121^{\circ} \mathrm{C}$ for $20 \mathrm{~min}$, as determined by inhibition of mycelial growth of C. gloeosporioides (Fig. S1). Numerous studies have reported that the culture filtrates of Bacillus genus have a broad spectrum of activities. The culture filtrate of B. safensis B21 showed antifungal activity against Magnaporthe oryzae, which causes rice blast disease (Rong et al. 2020). Dong et al. (2019) reported that culture filtrate of B. amyloliquefaciens $\mathrm{Rdx} 5$ strongly inhibited the growth of $M$. oryzae. These indicated the great potential of Bacillus genus in control plant disease.

\section{Antifungal activities of crude protein and crude lipopeptide extracts from sterile culture filtrate}

The 7 fungal phytopathogens that were strongly inhibited by the SCF were used to determine the antifungal activities of the crude protein extracts and crude lipopeptide extracts from the SCF. The crude protein and crude lipopeptide extracts strongly inhibited the growth of all 7 fungal phytopathogens, with inhibition rates in the range of 26.7 to $85.4 \%$ and 11.6 to $89.7 \%$, respectively (Fig. 2c). Many reports have shown that members of Bacillus genus can produce different antibiotics from culture filtrates that have strong antifungal activities. Proteins and lipopeptides are widely found in culture filtrates secreted by Bacillus genus. Lipopeptides and proteins in the culture filtrate produced by $B$. atrophaeus CAB-1 inhibited various fungal pathogens ( $F$. oxysporum, Verticillium dahlia, Rhizoctonia solani, and $B$. cinerea) (Zhang et al. 2013). Rong et al. (2020) reported that B. safensis B21 produced iturin A2 and A6 that inhibited the growth of hyphae of $M$. oryzae by changing membrane permeability. Ren et al. (2019) reported that a novel protein obtained from the culture filtrate of $B$. subtilis XB-1 inhibited the mycelial growth of M. fructicola.

\section{Antifungal activities of volatile compound(s)}

Strain ZSH-1 produced antifungal VOCs that reduced the mycelial growth of the 7 fungal phytopathogens with inhibition rates in the range of 7.8 to $63.2 \%$ (Fig. $2 a)$. The result consists with previous findings that VOCs produced by Bacillus genus had antifungal activities. Yuan et al. (2012) reported that the VOCs produced by $B$. amyloliquefaciens NJN-6 inhibited the growth and spore germination of $F$. oxysporum. Currently, the VOCs produced by Bacillus genus are generally grouped into amides, aldehydes, alcohols, ketones, and phenols. Zhang et al. (2013) reported that $O$-anisaldehyde is one of the most abundant VOCs produced by $B$. atrophaeus $\mathrm{CAB}-1$ with the highest inhibitory effect on the mycelial growth of $B$. cinerea. Three VOCs (2nonanone, $\beta$-benzeneethanamine, and 2-decanone) produced by $B$. pumilus and B. thuringiensis had great inhibitory effects on C. gloeosporioides (Zheng et al. 2013). VOCs of ZSH-1 probably contain many kinds of antifungal components, and different fungi have different sensitivities to the antifungal action of a same component, so there is difference in the inhibitory effects of VOCs from ZSH-1 against different fungal phytopathogens. Moreover, when the colony diameters of $C$. gloeosporioides were measured every $12 \mathrm{~h}$, the mycelial growth was significantly inhibited after $24 \mathrm{~h}$ by the 


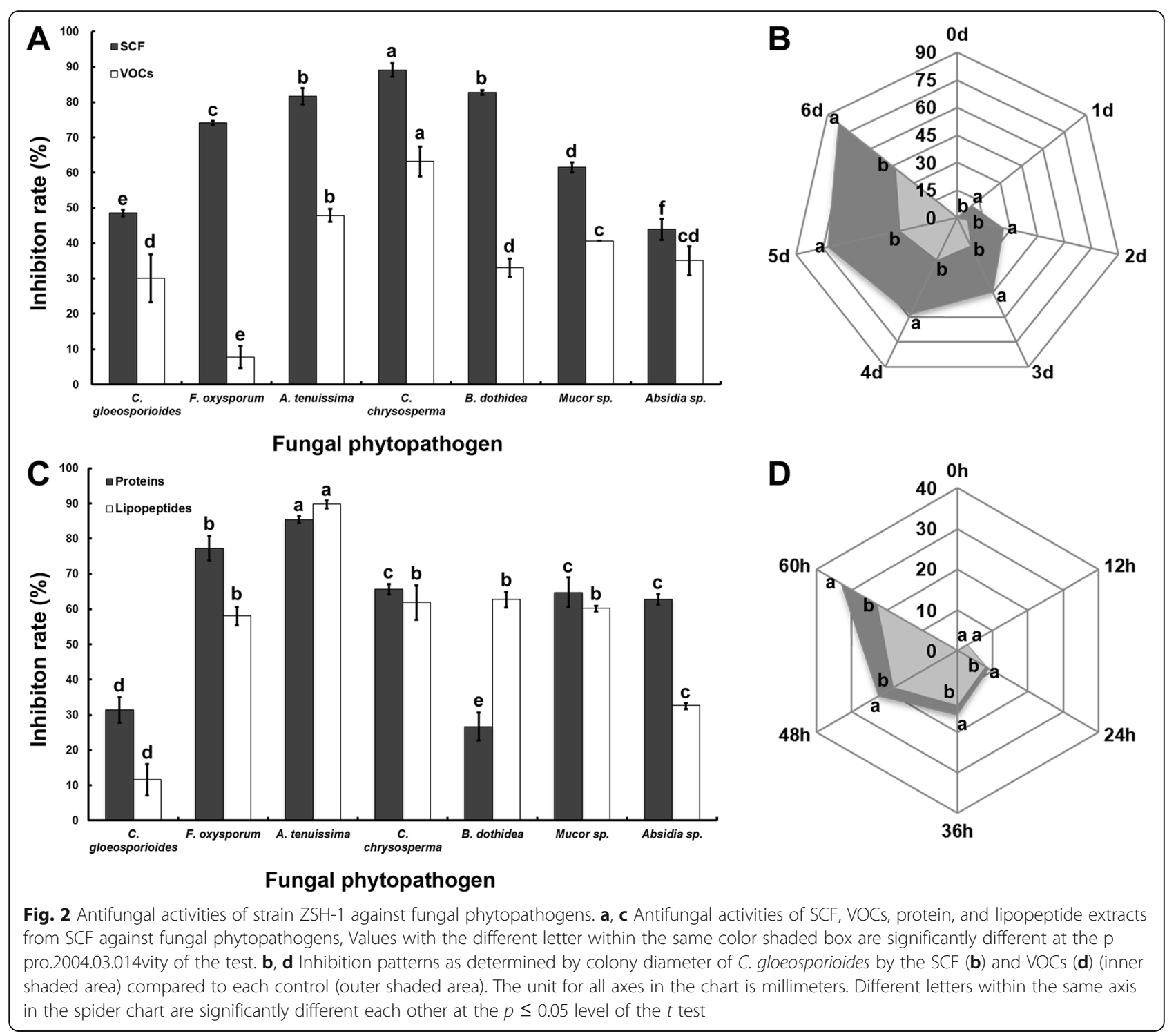

VOCs produced by strain ZSH-1, and there was a gradual increase in the inhibition rate from 0 to $60 \mathrm{~h}$ (Fig. $2 \mathrm{~d})$. This result is in agreement with the study that the inhibitory effect of volatiles produced by B. amyloliquefaciens NJN-6 gradually increased with treatment time (Yuan et al. 2012). The increasing inhibition rate may be due to the creation of a hypoxic environment by the antifungal bacteria (Boukaew et al. 2013).

\section{Cell wall-degrading traits}

The cell wall-degrading traits of strain $\mathrm{ZSH}-1$ was determined by the activities of 5 lytic enzymes (cellulose, $\beta-1$, 3 -glucanase, chitinase, protease, and lipase). When the colony of ZSH-1 was cultured after 4 days, clear zones around the colonies on different culture plates were observed. This indicated that $\mathrm{ZSH}-1$ have activities of cellulase (Fig. 3a), $\beta$-1,3-glucanase (Fig. 3b), and protease (Fig. 3c). No clear zone was found in the culture plates containing chitinase or lipase (not shown). Several cell wall-degrading enzymes such as chitinase, $\beta$-1,3-glucanase, cellulase, protease, and lipase are produced by $\mathrm{Ba}$ cillus species which are involved in the antifungal activity against fungal phytopathogens. The enzymes mainly play an important role in the decomposition of fungal cell walls and subsequent cell death (Tseng et al. 2008). Ren et al. (2013) reported that B. pumilus JK-SX001 produced cellulase and protease. Dong et al. (2019) demonstrated that cellulase and protease were secreted by $B$. amyloliquefaciens $\mathrm{Rdx} 5$. In the present study, the cell walldegrading traits of strain $\mathrm{ZSH}-1$ may be one reason that this bacterium is equally effective against different fungal phytopathogens with variable cell wall compositions. 


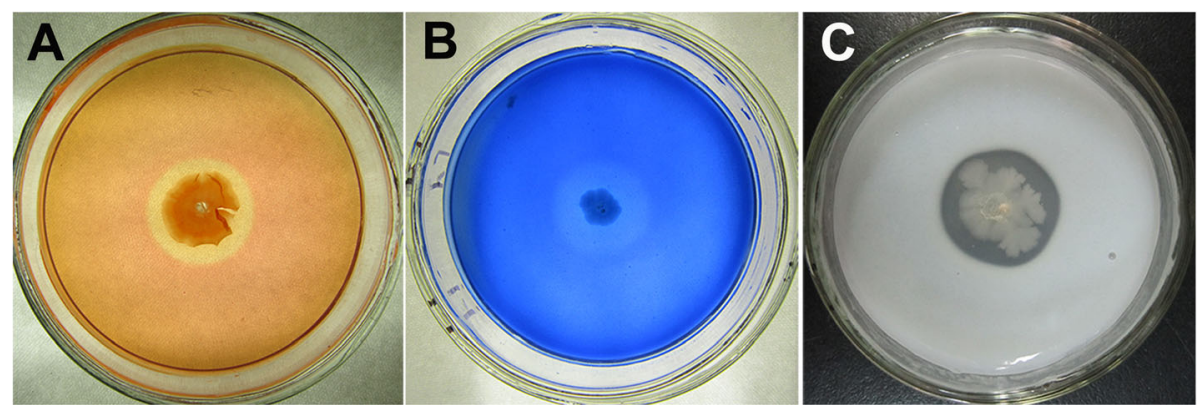

Fig. 3 Cell wall-degrading traits of strain ZSH-1. Production of cellulase (a), $\beta-1,3-$-glucanase (b), and protease (c) is indicated by clear zones around the colonies on the plates

\section{Evaluation of biocontrol activity of strain $\mathrm{ZSH}-1$ under greenhouse conditions}

At present, the main disease control measure for poplar anthracnose is done by applying with fungicides (Song et al. 2016). Many Bacillus species have been used as biocontrol agents for C. gloeosporioides that causes plant anthracnose (Fira et al. 2018; Guerrero-Barajas et al. 2020). However, used Bacillus species for control poplar anthracnose that caused by $C$. gloeosporioides is rarely reported. In the previous study, B. atrophaeus XW2 was used as an effective biocontrol agent against $C$. gloeosporioides, it had a $49.1 \%$ efficacy in controlling poplar anthracnose under controlled greenhouse conditions (Huang et al. 2014). In the present study, strain ZSH-1 obviously inhibited the development of poplar anthracnose in greenhouse experiments (Table 3). After 12 days inoculation, the diseased leaves rate and the disease index of plants inoculated with $\mathrm{ZSH}-1$ were significantly lower than the values of plants un-inoculated with $\mathrm{ZSH}$ 1. ZSH-1 had $47.6 \%$ control effect against poplar anthracnose that was caused by $C$. gloeosporioides. The leaves treated with sterile distilled water had no disease symptoms. The pot experiments in greenhouse indicated that strain ZSH-1 has a good biocontrol efficacy against C. gloeosporioides in vivo and can be used as a potential biocontrol agent for more study. However, biocontrol of the poplar anthracnose in the greenhouse may not effectively control the disease in the field. Additional studies about the biological characteristics of strain $\mathrm{ZSH}-1$,

Table 3 Efficacy of strain ZSH-1 in controlling poplar anthracnose under greenhouse conditions

\begin{tabular}{llll}
\hline Treatment & $\begin{array}{l}\text { Diseased leaves } \\
\text { rate (\%) }\end{array}$ & $\begin{array}{l}\text { Disease } \\
\text { index }\end{array}$ & $\begin{array}{l}\text { Greenhouse control } \\
\text { efficacy (\%) }\end{array}$ \\
\hline CK1 & $0 \pm 0 \mathrm{c}$ & $0 \pm 0 \mathrm{c}$ & $\backslash$ \\
$\mathrm{CK} 2$ & $54.3 \pm 3.0 \mathrm{a}$ & $25.0 \pm 3.0 \mathrm{a}$ & $\backslash$ \\
$\mathrm{SZ}$ & $37.5 \pm 3.0 \mathrm{~b}$ & $13.1 \pm 1.3 \mathrm{~b}$ & 47.6 \\
\hline
\end{tabular}

Values with the different letter within the same column are significantly different at $P \leq 0.05$ according to Duncan's test. Numbers followed by the " \pm " are standard errors (SE). " $\backslash$ " indicates the data is incalculable such as colonization, survival ability, and product formulation, are needed to confirm the biocontrol effect of strain ZSH-1 in the field (Liu et al. 2019). Meanwhile, the abilities of strain $\mathrm{ZSH}-1$ to promote plant growth and activate induced systemic resistance (ISR) of plant in the field should also be studied in the future (Lyu et al. 2019; Tiwari et al. 2019, and Jinal and Amaresan 2020).

\section{Conclusion}

In the present study, an antagonistic bacteria $B$. subtilis ZSH-1 against C. gloeosporioides from the rhizosphere soil of poplar was evaluated. The sterile culture filtrate, crude protein, and crude lipopeptide extracts from the culture filtrate and volatile compound(s) of $\mathrm{ZSH}-1$ strongly inhibited the fungal phytopathogens growth in vitro. Moreover, the greenhouse trial revealed that strain ZSH-1 had a good biocontrol efficacy in controlling C. gloeosporioides in vivo. Therefore, the results proved that $B$. subtilis $\mathrm{ZSH}-1$ can be used as a promising biocontrol agent against $C$. gloeosporioides and other fungal phytopathogens.

\section{Supplementary information}

Supplementary information accompanies this paper at https://doi.org/10. 1186/s41938-020-00301-5.

Additional file 1: Fig. S1. Effect of temperature on antifungal activity of sterile culture filtrate of strain $\mathrm{ZSH}-1$

\section{Abbreviations}

DI: Disease index; DS: Disease severity; DLR: Diseased leaves rate; GCE: Greenhouse control efficacy; LB: Luria-Bertani; PDA: Potato dextrose agar; SCF: Sterile culture filtrate; TYB: Tryptone yeast extract broth; VOCs: Volatile compound(s)

\section{Acknowledgements}

Not applicable.

\section{Authors' contributions}

First author $\mathrm{HH}$ participated in the planning and designing of the experiments, implementation of the experiments, and writing of the manuscript. CM conceived of the study and participated in its design and coordination. YH participated in drafting the manuscript. The fourth author $\mathrm{HH}$ participated in 
revising the paper scientifically and checking analysis. All authors read and approved the final manuscript.

\section{Funding}

The research was supported by the Guangdong Basic and Applied Basic Research Foundation (2019A1515011814), Forestry Science and Technology Innovation Project of Guangdong (2020KJCX004)

\section{Availability of data and materials}

All data and materials are available.

\section{Ethics approval and consent to participate}

Not applicable.

\section{Consent for publication}

Not applicable.

\section{Competing interests}

The authors declare that they have no competing interests.

\section{Author details}

${ }^{1}$ Guangdong Provincial Key Laboratory of Silviculture, Protection and Utilization, Guangdong Academy of Forestry, Guangzhou 510520, Guangdong, China. ${ }^{2}$ College of Forestry, Beijing Forestry University, Beijing 100083, China

Received: 1 April 2020 Accepted: 21 July 2020

Published online: 11 August 2020

\section{References}

Baysal Ö, Lai D, Xu HH, Siragusa M, Çalışkan M, Carimi F, Da Silva JAT, Tör M (2013) A proteomic approach provides new insights into the control of soilborne plant pathogens by Bacillus species. PLoS One 8:e53182. https://doi. org/10.1371/j.pone.0053182

Boukaew S, Plubrukam A, Prasertsan P (2013) Effect of volatile substances from Streptomyces philanthi RM-1-138 on growth of Rhizoctonia solani on rice leaf. BioControl 58:471-482. https://doi.org/10.1007/s10526-013-9510-6

Dong XZ, Cai MY, Lu YY, Xie JY, Liu XL (2001) Identification methods of common bacteria. In: Dong XZ, Cai MY (eds) Handbook of common bacteria systematic identify. Beijing Science press, Beijing, pp 349-398

Dong Y, Li H, Rong S, Xu H, Guan Y, Zhao L, Chen W, He X, Gao X, Chen R, Li L, Xu Z (2019) Isolation and evaluation of Bacillus amyloliquefaciens Rdx5 as a potential biocontrol agent against Magnaporthe oryzae. Biotechnol Biotec Eq 33:408-418. https://doi.org/10.1080/13102818.2019.1578692

Essghaier B, Fardeau ML, Cayol JL, Hajlaoui MR, Boudabous A, Jijakli H, SadfiZouaoui N (2009) Biological control of grey mould in strawberry fruits by halophilic bacteria. J Appl Microbiol 106:833-846. https://doi.org/10.1111/j. 1365-2672.2008.04053.x

Fira D, Dimkić I, Berić T, Lozo J, Stanković S (2018) Biological control of plant pathogens by Bacillus species. J Biotechnol 285:44-55. https://doi.org/10. 1016/j.jbiotec.2018.07.044

Furuya S, Mochizuki M, Aoki Y, Kobayashi H, Takayanagi T, Shimizu M, Suzuki S (2011) Isolation and characterization of Bacillus subtilis KS1 for the biocontrol of grapevine fungal diseases. Biocontrol Sci Tech 21:705-720. https://doi.org/ 10.1080/09583157.2011.574208

Gao X, Tu X, Huang L, Luo P (2009) The screen of plant endophytic actinomycetes producing $\beta-1,3$-glucanase and antifungal activity of $\beta-1,3-$ glucanase. Microbiology 36:1189-11194. doi: https://doi.org/10.13344/j. microbiol.china.2009.08.021

Guerrero-Barajas C, Constantino-Salinas EA, Amora-Lazcano E, Tlalapango-Ángeles D, Mendoza-Figueroa JS, Cruz-Maya JA, Jan-Roblero J (2020) Bacillus mycoides A1 and Bacillus tequilensis A3 inhibit the growth of a member of the phytopathogen Colletotrichum gloeosporioides species complex in avocado. J Sci Food Agric. https://doi.org/10.1002/jsfa.10450

Guo Q, Li Y, Lou Y, Shi M, Jiang Y, Zhou J, Sun Y, Xue Q, Lai H (2019) Bacillus amyloliquefaciens Ba13 induces plant systemic resistance and improves rhizosphere microecology against tomato yellow leaf curl virus disease. Appl Soil Ecol 137:154-166. https://doi.org/10.1016/j.apsoil.2019.01.015

Huang HY, Wu ZQ, Tian CM, Liang YM, You CJ, Chen L (2014) Identification and characterization of the endophytic bacterium Bacillus atrophaeus XW2, antagonistic towards Colletotrichum gloeosporioides. Ann Microbiol 65:13611371. https://doi.org/10.1007/s13213-014-0974-0

Islam MA, Nain Z, Alam MK, Banu NA, Islam MR (2018) In vitro study of biocontrol potential of rhizospheric Pseudomonas aeruginosa against Fusarium oxysporum f. sp. cucumerinum. Egypt J Biol Pest Control 28:90. https://doi. org/10.1186/s41938-018-0097-1

Jinal NH, Amaresan N (2020) Evaluation of biocontrol Bacillus species on plant growth promotion and systemic-induced resistant potential against bacterial and fungal wilt-causing pathogens. Arch Microbiol. https://doi.org/10.1007/ s00203-020-01891-2

Karthika S, Midhun SJ, Jisha MS (2020) A potential antifungal and growthpromoting bacterium Bacillus sp. KTMA4 from tomato rhizosphere. Microb Pathog 142:104049. https://doi.org/10.1016/j.micpath.2020.104049

Kurabachew H, Wydra K (2013) Characterization of plant growth promoting rhizobacteria and their potential as bioprotectant against tomato bacterial wilt caused by Ralstonia solanacearum. Biol Control 67:75-83. https://doi.org/ 10.1016/j.biocontrol.2013.07.004

Li Z, Liang Y, Tian C (2012) Characterization of the causal agent of poplar anthracnose occurring in the Beijing region. Mycotaxon 120:277-286

Liu Y, Qiao J, Liu Y, Liang X, Zhou Y, Liu J (2019) Characterization of Lysobacter capsici strain NF87-2 and its biocontrol activities against phytopathogens. Eur J Plant Pathol 155:859-869. https://doi.org/10.1007/s10658-019-01817-9

Lyu D, Backer RG, Robinson WG, Smith DL (2019) Plant-growth promoting rhizobacteria for cannabis production: yield, cannabinoid profile and disease resistance. Front Microbiol 10:1761. https://doi.org/10.3389/fmicb.2019.01761

Pérez-García A, Romero D, De Vicente A (2011) Plant protection and growth stimulation by microorganisms: biotechnological applications of Bacilli in agriculture. Curr Opin Biotechnol 22:187-193. https://doi.org/10.1016/j. copbio.2010.12.003

Ren JH, Li H, Wang YF, Ye JR, Yan AQ, Wu XQ (2013) Biocontrol potential of an endophytic Bacillus pumilus JK-SX001 against poplar canker. Biol Control 67: 421-430. https://doi.org/10.1016/j.biocontrol.2013.09.012

Ren J, He W, Li C, He S, Niu D (2019) Purification and identification of a novel antifungal protein from Bacillus subtilis XB-1. World J Microbiol Biotechnol 35: 150. https://doi.org/10.1007/s11274-019-2726-6

Rong S, Xu H, Li L, Chen R, Gao X, Xu Z (2020) Antifungal activity of endophytic Bacillus safensis B21 and its potential application as a biopesticide to control rice blast. Pestic Biochem Physiol 162:69-77. https://doi.org/10.1016/j.pestbp. 2019.09.003

Shafi J, Tian H, Ji M (2017) Bacillus species as versatile weapons for plant pathogens: a review. Biotechnol Biotec Eq 31:446-459. https://doi.org/10. 1080/13102818.2017.1286950

Song Q, Huang Y, Yang H (2012) Optimization of fermentation conditions for antibiotic production by Actinomycetes YJ1 strain against Sclerotinia sclerotiorum. J Agric Sci 4:95-102. https://doi.org/10.5539/jas.v4n7p95

Song D, Zhang Y, Zhang $L$ (2016) Sensitivities of poplar anthracnose fungi isolates to carbendazim and three C-14a-demethylation inhibitors. Chin J Pestic Sci 18:567-574. https://doi.org/10.16801/j.issn.1008-7303.2016.0079

Tiwari S, Prasad V, Lata C (2019) Bacillus: Plant growth promoting bacteria for sustainable agriculture and environment. In: New and future developments in microbial biotechnology and bioengineering. (pp. 43-55). Elsevier, Amsterdam, pp 43-55. https://doi.org/10.1016/B978-0-444-64191-5.00003-1

Todorova S, Kozhuharova L (2010) Characteristics and antimicrobial activity of Bacillus subtilis strains isolated from soil. World J Microbiol Biotechnol 26: 1207-1216. https://doi.org/10.1007/s11274-009-0290-1

Tseng SC, Liu SY, Yang HH, Lo CT, Peng KC (2008) Proteomic study of biocontrol mechanisms of Trichoderma harzianum ETS 323 in response to Rhizoctonia solani. J Agric Food Chem 56:6914-6922. https://doi.org/10.1021/jf703626j

Yang CJ, Zhang XG, Shi GY, Zhao HY, Chen L, Tao K, Hou TP (2011) Isolation and identification of endophytic bacterium W4 against tomato Botrytis cinerea and antagonistic activity stability. Afr J Microbiol Res 5:131-136. https://doi. org/10.5897/AJMR10.81

Yu Q, Liu Z, Lin D, Zhang W, Sun Q, Zhu J, Lin M (2013) Characterization and evaluation of Staphylococcus sp. strain LZ16 for the biological control of rice blast caused by Magnaporthe oryzae. Biol Control 65:338-347. https://doi.org/ 10.1016/j.biocontrol.2013.03.016

Yuan J, Raza W, Shen QR, Huang QW (2012) Antifungal activity of Bacillus amyloliquefaciens NJN-6 volatile compounds against Fusarium oxysporum f. sp. cubense. Appl Environ Microbiol 78:5942-5944. https://doi.org/10.1128/ AEM.01357-12 
Zhang XY, Li BQ, Wang YG, Guo QG, Lu XY, Li SZ, Ma P (2013) Lipopeptides, a novel protein, and volatile compounds contribute to the antifungal activity of the biocontrol agent Bacillus atrophaeus CAB-1. Appl Microbiol Biotechnol 97:9525-9534. https://doi.org/10.1007/s00253-013-5198-x

Zheng M, Shi JY, Shi J, Wang QG, Li YH (2013) Antimicrobial effects of volatiles produced by two antagonistic Bacillus strains on the anthracnose pathogen in postharvest mangos. Biol Control 65:200-206. https://doi.org/10.1016/j. cropro.2004.03.014

\section{Publisher's Note}

Springer Nature remains neutral with regard to jurisdictional claims in published maps and institutional affiliations.

\section{Submit your manuscript to a SpringerOpen ${ }^{\circ}$ journal and benefit from:}

- Convenient online submission

- Rigorous peer review

- Open access: articles freely available online

- High visibility within the field

- Retaining the copyright to your article

Submit your next manuscript at $\boldsymbol{\nabla}$ springeropen.com 